\title{
POTENSI EKSTRAK DAUN SALAM (Syzygium polyanthum) PADA pH ASAM SEBAGAI SENSITIZER PADA DYE SENSITIZED SOLAR CELL (DSSC)
}

\author{
Elsa Rishda Hariningtias, Pirim Setiarso * \\ Departemen Kimia, Fakultas Matematika dan Ilmu Pengetahuan Alam, Universitas Negeri Surabaya \\ *email : pirimsetiarso@unesa.ac.id
}

Received 7 Oktober 2021

Accepted 3 Desember 2021

\begin{abstract}
Abstrak
Penelitian dilakukan untuk mengetahui potensi ekstrak daun salam (Syzygium polyanthum) dalam $\mathrm{pH}$ asam sebagai sensitizer pada DSSC. Pada penelitian ini teknik ekstraksi yang digunakan adalah teknik maserasi. Sampel ekstrak daun salam dikarakterisasi dengan menggunakan alat instrumen Spektrofotometer UV-Vis dan Voltameter Siklik untuk mengetahui potensi yang dihasilkan oleh molekul zat warna tersebut sebagai sansitizer pada DSSC. Dari spektrum serapan UV-Vis diketahui bahwa ekstrak daun salam mengandung pigmen klorofil, hal ini dikarenakan puncak serapan maksimal ekstrak daun salam berada pada panjang gelombang 468,50 $\mathrm{nm}$ yang diduga merupakan klorofil a dan 662, $50 \mathrm{~nm}$ yang diduga merupakan klorofil b. Dari karakterisasi dengan menggunakan voltameter siklik didapatkan hasil terbaik pada ekstrak daun salam pH 1 dengan energi gap sebesar 0,60699 $\mathrm{eV}$.
\end{abstract}

Kata kunci: DSSC, pH, potensi, klorofil. sensitizer

\begin{abstract}
The study was conducted to determine the potential of salam leaf (Syzygium polyanthum) extract in acidic pH as a sensitizer in DSSC (Dye Sensitized Solar Cell). In this study, the extraction technique used is the maceration technique. Samples of salam leaf extract were characterized using UV-Vis Spectrophotometer and Cyclic Voltameter instruments to determine the potential produced by the dye molecules as a sanitizer in DSSC. From the UV-Vis absorption spectrum, it is known that salam leaf extract contains chlorophyll pigment, this is because the maximum absorption peak of bay leaf extract is at a wavelength of $468.50 \mathrm{~nm}$ which is thought to be chlorophyll a and $662.50 \mathrm{~nm}$ which is thought to be chlorophyll b. From the characterization using a cyclic voltameter, the best results were obtained in the salam leaf extract $\mathrm{pH} 1$ with an energy gap of $0.60699 \mathrm{eV}$.
\end{abstract}

Keywords: DSSC, $p H$, potential, chlorophyll, sensitizer

\section{Pendahuluan}

Kebutuhan energi terutama energi listrik semakin hari semakin meningkat, namun kebutuhan tersebut belum dapat terpenuhi dengan maksimal. Beberapa energi alternatif dapat dimanfaatkan dengan maksimal untuk menangani krisis energi listrik tersebut, salah satunya yaitu dengan memanfaatkan sumber energi matahari. Pemanfaatan sumber energi matahari biasa dikenal dengan pembangkit listrik tenaga surya fotofoltaic (PLTTF) (M. A. M. Al-Alwani, 2019), (S. R. Alfidharisti, 2017), (J. Gong, 2017).

Dalam perkembangan teknologi, para ilmuwan mengembangkan energi alternatif yaitu sel surya menjadi suatu perangkat fotoelektrokimia DSSC. (K. Wongcharee, 2007), (S. Kim, 2006). DSSC (Dye Sensitized Solar Cell) dikenalkan pertama 
kali oleh O'Regan dan Grätzel pada tahun 1991 (Grätzel B. O., 1991). DSSC merupakan salah satu perangkat fotovoltaic, DSSC tersusun dari dari elektroda kerja semikonduktor, elektroda lawan, elektrolit dan molekul zat warna (J. Bisquert, 2003). DSSC bekerja dengan mengkonversikan atau mengubah foton yang ditangkap dari energi matahari menjadi energi listrik (Grätzel M. , 2003). Dimana molekul pewarna yang berada pada permukaan semikonduktor $\mathrm{TiO}_{2}$ akan menyerap foton dari cahaya matahari. Molekul zat pewarna yang menyerap foton akan tereksitasi dari HOMO menuju LUMO. Saat proses eksitasi elektronelektron akan terkumpul pada permukaan semikonduktor dan molekul zat pewarna mengalami oksidasi. Elektron yang terkumpul akan ditransfer melalui $\mathrm{TiO}_{2}$ menuju elektroda lawan dan pada proses tersebut menghasilkan energi listrik.

Potensi kerja DSSC bergantung pada molekul zat warna yang digunakan dan luas semikonduktor celah pita. Semikonduktor celah pita yang biasa digunakan adalah $\mathrm{TiO}_{2}$, hal ini dikarenakan $\mathrm{TiO}_{2}$ memiliki karakteristik optik yang baik untuk terus menerus mentransfer elektron (K. Tennakone, 1996). Molekul zat warna alami yang sering dimanfaatkan karena memiliki potensi biodegradasi maksimal antara lain adalah klorofil, antosianin, kartenoid, betalains, flavonoid, sianin, dan tanin (AlAlwani, et al., 2017).

Potensi setiap molekul zat warna yang dimanfaatkan sebagai sensitizer pada DSSC berbeda-beda pada setiap tumbuhan. Potensi molekul zat warna bergantung pada struktur kimia pigmen warna tersebut dan tingkat adsorpsi atau peristiwa perpindahan elektron valensi molekul ke tingkat energi orbital yang lebih tinggi menuju permukaan semikonduktor (Setiarso., 2016).

Salah satu penyebab kinerja molekul zat warna alami sebagai sensitizer dalam DSSC menjadi buruk yaitu dikarena kemampuan menyerap foton yang sangat lemah pada permukaan semikonduktor, sehingga mengakibatkatkan berkurangnya electron yang terkumpul (Al-Alwani, et al., 2017).

Dalam penelitian ini penulis akan menganalisis potensi molekul zat warna alami ekstrak daun salam (Syzygium polyanthum) pada $\mathrm{pH}$ asam yang akan dimanfaatkan sebagai sensitizer pada DSSC. Daun salam dipilih karena memiliki kandungan klorofil, pada beberapa penelitian menunjukan bahwa potensi klorofil sebagai sensitizer memiliki efesiensi yang cukup baik dan cocok sebagai sensitizer pada daerah visibel atau tampak. Hal ini dikarenakan klorofil menyerap berbagai cahaya dari panjang gelombang warna merah, biru dan ungu dengan cara mencerminkan panjang gelombang hijau (Syafinara, Gomesh, Irwanto, Fareq, \& Irwan, 2015). Sebagian besar klorofil ditemukan pada tumbuhan terutama daun yang memiliki warna hijau. Puncak serapan klorofil kuat pada daerah tampak terletak pada 420-660 nm (AlAlwani MAM, 2015). Terdapat enam jenis klorofil di alam. Dua jenis klorofil utama yang sering terdapat dalam tumbuhan adalah klorofil a dan klorofil b. Klorofil a dengan rentang panjang gelombang yang terletak pada $400-500 \mathrm{~nm}$ paling banyak menyerap cahaya ungu dan jingga, sedangkan klorofil $b$ dengan rentang panjang gelombang yang terletak pada 600-700 $\mathrm{nm}$ sebagian besar menyerap cahaya biru dan kuning. Kedua panjang gelombang klorofil juga menyerap cahaya dari panjang gelombang lainnya kecuali hijau, namun dengan intensitas penyerapan yang lebih kecil (Milne, Toker, Rubio, \& Nielsen, 2015).

Efisiensi kinerja konversi fotovoltaic pigmen klorofil berdasarkan yang telah dilaporkan sebelumnya, seperti bayam digunakan sebagai sensitizer berbasis alami dan kinerja fotovoltaic menunjukkan sirkuit terbuka tegangan (Voc) sebesar 550 $\mathrm{mV}$, arus hubung singkat (Isc) sekitar 0,46 $\mathrm{mA}$ dan fill factor (FF) sekitar 51\% (Chang $\mathrm{H}, 2010)$. Gugus karboksilat yang terdapat 
pada klorofil menjadikan klorofil sangat berpotensi dalam mengkonversi energi, hal ini dikarenakan gugus karboksilat yang terdapat pada klorofil dapat berikatan dengan $\mathrm{TiO}_{2}$ (Muhandri., 2019).

Klorofil merupakan molekul zat warna yang peka terhadap panas, oksigen dan degradasi kimia. Degradasi klorofil dipengaruhi oleh $\mathrm{pH}$. Pada penelitian ini penulis menggunakan $\mathrm{pH}$ asam dikarenakan berdasarkan penelitian yang telah dilakuakan oleh Azizah (2018) menunjukan bahwa klorofil yang berada pada $\mathrm{pH}$ asam memiliki potensi atau efisiensi yang lebih tinggi dibandingkan dengan klorofil pada $\mathrm{pH}$ basa. Kondisi tersebut ditunjukan oleh hasil FTIR klorofil pada $\mathrm{pH}$ asam mengalami electronic coupling antara LUMO dan $\mathrm{TiO}_{2}$, menyebabkan level Fermi $\mathrm{TiO}_{2}$ dan potensial elektrolit berkurang dengan seiring bertambahnya ion $\mathrm{H}^{+}$, sehingga proses transfer elektron meningkat.

Pemilihan daun salam pada penilitian dikarenakan daun salam banyak ditemukan di Asia yang melimpah di Indonesia, namun pemanfaatannya belum maksimal. Daun salam biasanya hanya digunakan sebagai bahan pelengkap bumbu masakan, sehingga perlu dikembangkan lagi pemanfaatannya. Analisis menggunakan spektrofotometer UV-Vis untuk mengetahui serapan panjang gelombang pewarna, dan voltameter siklik digunakan untuk menentukan keadaan HOMO dan LUMO klorofil.

\section{Metode Penelitian \\ Alat dan bahan}

Alat serta instrument yang diperlukan dalam penelitian ini adalah spektrofotometer UV-Vis Shimadzu 1800, Voltameter 797 VA Computrace, dan alat gelas. Bahan yang diperlukan untuk penelitian ini adalah Daun salam (Syzygium polyanthum) yang diperoleh dari daerah menanggal Surabaya, pelarut etanol P.A 96\% (MERCK), $\mathrm{HCl} \mathrm{1,2 \% ,}$ kertas saring, aluminium foil dan $\mathrm{KCl} 3 \mathrm{M}$.

\section{Persiapan Sampel}

Sampel bahan yang digunakan pada penelitian ini berupa daun salam segar. Daun salam segar dibersihkan dengan air mengalir dan ditiriskan hingga kering. Daun salam dipotong hinga ukurannya menjadi kecil-kecil.

\section{Proses Ekstraksi}

Daun salam yang telah dipotongi kecilkecil sebanyak 8 gram dimaserasi dengan menggunakan pelarut etanol P.A $96 \%$. Perbandingan antara sampel daun salam dan pelarut untuk proses maserasi adalah 1:5. Pada penelitian ini variasi yang digunakan adalah variasi $\mathrm{pH}$ pelarut. $\mathrm{pH}$ yang digunakan untuk memvariasi sifat pelarutnya adalah $\mathrm{pH}(1,2,3,4,5,6,7)$. Proses ekstraksi secara maserasi pada penelitian ini dilakukan selama 24 jam. Setelah 24 jam, sampel disaring dengan menggunkan corong dan kertas saring untuk memisahkan filtrat dan residunya.

\section{Proses Karakterisasi Daun Salam}

pH pada setiap sampel akan sangat mempengaruhi reaksi yang terjadi. larutan sampel ekstrak daun salam dikarakterisasi dengan menggunakan alat Instrumen spektofotometri UV-Vis dan voltameter. Kemudian hasil karakterisasi dari kedua alat tersebut diolah dengan menggunakan aplikasi Origin Pro 2018 (Rimbi Rodiyana Sova and Pirim Setiarso, 2021).

\section{Karakterisasi spektrofotometri UV-Vis} ekstrak daun salam

Karakterisasi larutan sampel pewarna dilakukan di Laboratorium Instrumen Spektofotometri UV-Vis yang berada pada jurusan Kimia FMIPA Unesa. Karakterisasi ini bertujuan untuk mengetahui serapan panjang gelombang maksimal daun salam pada setiap $\mathrm{pH}$. Rentang panjang gelombang yang digunakan untuk menguji sampel ekstrak daun salam antara 400-800 $\mathrm{nm}$, hal ini dilakukan karena pada rentang tersebut merupakan daerah tampak (D. Ganta, 2017). 
Karakterisasi voltametri siklik ekstrak daun salam

Karakterisasi voltametri siklik pada larutan sampel dilakukan di Laboratorium instrumen voltameter tipe 797 VA Computrace yang berada di Jurusan Kimia FMIPA Unesa. Karakterisasi ini dilakukan untuk menentukan keadaan HOMO LUMO. Pewarna sansitizer harus memiliki nilai HOMO yang lebih rendah dari potensi redoks elektrolit dan pita konduksi, sedangkan keadaan LUMO pewarna harus lebih tinggi dari pita konduksi semikonduktor (K. Sharma, 2018), (Muhandri., 2019), (L. G. Oktariza, 2018). Dalam pengukuran digunakan KCL 3M sebagai elektrolit pendukung dan elektroda kerja berupa kawat tembaga. Penulis menggunakan start potensial -1.0 Volt dan end potensial 1.0 Volt, sedangkan sweeprate yang digunakan adalah 0.02 $\mathrm{V} / \mathrm{s}$.

\section{Hasil dan Pembahasan}

Pada penelitian ini dilakukan ekstraksi klorofil pada daun salam dengan variasi $\mathrm{pH}(1,2,3,4,5,6,7)$, dengan menggunakan metode maserasi atau perendaman selama 24 jam. Hasil dari maserasi daun salam dari $\mathrm{pH} 1$ sampai dengan $\mathrm{pH}$ 7. Pigmen warna alami yang dihasilkan dari maserasi daun salam berwarna kuning kehijauan hingga hijau pekat yang, hal ini membuktikan bahwa ekstrak daun salam mengandung senyawa klorofil (Rendy Rohmatul Maulid, 2015), (Sumenda, 2011).

Dalam karakterisasi menggunakan spektrofotometer UV-Vis, dilakukan pengukuran serapan panjang gelombang ekstrak daun salam pada pelarut etanol dengan variasi $\mathrm{pH}(1,2,3,4,5,6,7)$ dengan rentang 400-700 $\mathrm{nm}$.

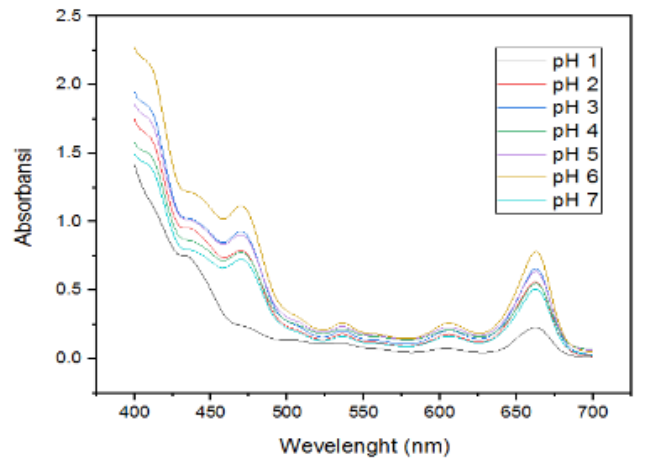

Gambar 1 Spektra absorbsi ekstrak daun salam pada pelarut etanol dengan variasi $\mathrm{pH}(1,2,3,4,5,6,7)$

Pada Gambar 1 memperlihatkan hasil dari analisis puncak panjang gelombang ekstrak daun salam dari $\mathrm{pH} 1$ sampai dengan $\mathrm{pH} 7$ dengan menggunakan spektrofotometri UV-Vis terdapat pada rentang 400-700 nm. Hal ini sesuai dengan penelitian sebelumnya yang dilakukan oleh (Syafinara, Gomesh, Irwanto, Fareq, \& Irwan, 2015), bahwa puncak serapan klorofil baik pada daerah visible yang terletak pada 400-700. Pada Gambar 1 terlihat bahwa panjang gelombang maksimal klorofil pada daun salam berada pada kisaran 450-700 $\mathrm{nm}$.

Tabel 1. Puncak Panjang Gelombang Maksimum Ekstrak Dye Daun Salam

\begin{tabular}{ccc}
\hline pH & $\begin{array}{c}\text { Panjang gelombang } \\
(\mathbf{n m}) \text { maksimum } \\
\text { ekstrak daun salam }\end{array}$ & $\begin{array}{c}\text { Jenis } \\
\text { klorofil }\end{array}$ \\
\hline $\mathbf{1}$ & 662,50 & Klorofil b \\
$\mathbf{2}$ & 662 & Klorofil b \\
& 469 & Klorofil a \\
$\mathbf{3}$ & 662,50 & Klorofil b \\
& 468,50 & Klorofil a \\
$\mathbf{4}$ & 662,50 & Klorofil b \\
& 469 & Klorofil a \\
$\mathbf{5}$ & 662,50 & Klorofil b \\
& 469,50 & Klorofil a \\
$\mathbf{6}$ & 662,50 & Klorofil b \\
& 469 & Klorofil a \\
$\mathbf{7}$ & 662,50 & Klorofil b \\
& 469 & Klorofil a \\
\hline
\end{tabular}


Pada Tabel 1 memperlihatkan hasil panjang gelombang maksimum ekstrak daun salam dari $\mathrm{pH} 2$ sampai dengan $\mathrm{pH} 7$ yang memiliki dua puncak panjang gelombang maksimum, panjang gelombang tersbut merupakan bagian dari klorofil a dan klorofil b. Pada klorofil a menempati puncak panjang gelombang dengan kisaran 400-500 nm dan puncak panjang gelombang maksimum klorofil $\mathrm{b}$ berada pada kisaran 600-700. (Milne, Toker, Rubio, \& Nielsen, 2015) (Rossi., 2017).

Pada ekstrak daun salam dengan $\mathrm{pH} 1$ hanya memiliki satu puncak panjang gelombang maksimum yaitu pada panjang gelombang $662.50 \mathrm{~nm}$, hal ini memperlihatkan bahwa pada $\mathrm{pH} 1$ hanya terdeteksi satu senyawa saja yaitu klorofil b. Pada pH 2, 3, 4, 5, 6, 7 selain terdeteksi memiliki puncak gelombang pada klorofil $\mathrm{b}$ dengan besar panjang gelombang 662.50 nm, pada $\mathrm{pH} 2,3,4,5,6,7$ juga terdeteksi adanya puncak panjang gelombang lain yaitu panjang gelombang $469 \mathrm{~nm}$ dan pada panjang gelombang tersebut merupakan panjang gelombang senyawa klorofil a (Rossi., 2017).

Hasil karakterisasi ekstrak daun salam menggunakan spektrofotometer UV-Vis menunjukan bahwa ekstrak daun salam pada berbagai variasi $\mathrm{pH}$ mengandung senyawa klorfil, sehingga ekstrak daun salam berpotensi sebagai sensitizer pada DSSC. Hal ini sesuai dengan penelitian sebelumnya, bahwa gugus karboksilat yang terdapat pada klorofil menjadikan klorofil sangat berpotensi dalam mengkonversi energi, gugus karboksilat yang terdapat pada klorofil dapat berikatan dengan $\mathrm{TiO}_{2}$ (Muhandri., 2019).

Dalam karakterisasi elektrokimia, penting untuk diketahui HOMO LUMO pada molekul zat warna. Molekul zat warna diharuskan memiliki HOMO lebih rendah dibandingkan dengan potensi redoks elektrolit dan pita konduksi, sedangkan nilai LUMO harus lebih tinggi dari pita konduksi semikonduktor (K.
Sharma, 2018), (Muhandri., 2019), (L. G. Oktariza, 2018).

Karakterisasi molekul zat warna ekstrak klorofil menggunakan voltameter siklik dilakukan dengan $25 \mathrm{ml}$ larutan campuran ekstrak daun salam pada masing- masing pH dengan KCL 3M sebagai elektrolit pendukung. Start potensial yang digunakan pada proses karakterisasi ini adalah -1.0 Volt dan end potensial 1.0 Volt, sedangkan sweeprate yang digunakan adalah $0.02 \mathrm{~V} / \mathrm{s}$. Hasil dari pengukuran diolah dengan mengunakan aplikasi Origin Pro 2018.

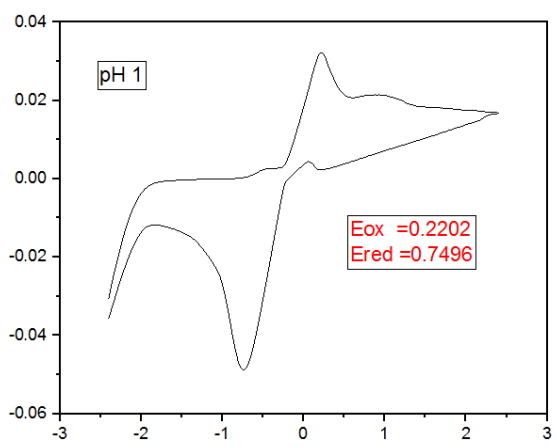

Gambar 2. Voltamogram ekstrak klorofil daun salam pada $\mathrm{pH} 1$

Pada Gambar 2 memperlihatkan hasil voltamogram dari ekstrak klorofil daun salam pada $\mathrm{pH}$ 1. Pada hasil volmatogram diamati HOMO LUMO pada molekul zat warna. HOMO merupakan proses oksidasi, sedangkan LUMO merupakan proses reduksi pada analit (D. Sinha, 2020).

Tabel 2. HOMO LUMO Ekstrak Klorofil Daun Salam

\begin{tabular}{ccc}
\hline $\mathbf{p H}$ & HOMO $(\mathbf{e V})$ & LUMO $(\mathbf{e V})$ \\
$\mathbf{1}$ & -4.554 & -3.947 \\
$\mathbf{2}$ & -4.560 & -3.935 \\
$\mathbf{3}$ & -4.572 & -3.775 \\
$\mathbf{4}$ & -4.620 & -3.876 \\
$\mathbf{5}$ & -4.560 & -3.828 \\
$\mathbf{6}$ & -4.614 & -3.733 \\
$\mathbf{7}$ & -4.578 & -3.793 \\
\hline
\end{tabular}

Pada Tabel 2 diketahui bahwa HOMO pada daun salam dari $\mathrm{pH} 1$ sampai dengan pH 7 memiliki nilai yang lebih rendah dibandingkan dengan nilai energi pita 
konduksi $\mathrm{TiO}_{2}(-3.2 \mathrm{eV})$ (Aryanti., 2016), (D. Ganta, 2017). Hal ini menunjukan bahwa ekstrak daun salam memiliki kemampuan yang baik sebagai sensitizer untuk mentransfer elektron ke pita konduksinya (Prajitno., 2015).

Energi gap diperoleh dengan mengurangkan LUMO dengan HOMO, semakin kecil energy gap pada molekul zat warna maka semakin baik potensi molekul zat warna tersebut untuk proses transfer electron, hal ini dikranekan pada proses transfer electron tidak memerlukan energy yang besar (Gusiak, 2011).

Tabel 3. Hasil Nilai Energi Gap Ekstrak

\begin{tabular}{cc}
\multicolumn{2}{c}{ Dye Daun Salam } \\
\hline $\mathbf{p H}$ & Band gap energy $(\mathrm{eV})$ \\
\hline $\mathbf{1}$ & 0.606 \\
$\mathbf{2}$ & 0.624 \\
$\mathbf{3}$ & 0.797 \\
$\mathbf{4}$ & 0.743 \\
$\mathbf{5}$ & 0.731 \\
$\mathbf{6}$ & 0.880 \\
$\mathbf{7}$ & 0.815 \\
\hline
\end{tabular}

Pada Tabel 3 ditunjukkan bahwa $\mathrm{pH} 1$ memiliki nilai energi gap terkecil yaitu sebesar 0.606. Hal ini menunjukan bahwa ekstrak klorofil daun salam dengan $\mathrm{pH} 1$ merupakan ekstrak yang memiliki kemampuan terbaik sebagai sensitizer, hal ini dikarenakan energi gap ekstrak klorofil daun salam dengan $\mathrm{pH} 1$ memiliki nilai terkecil dibadingkan dengan ekstrak lainnya. Ekstrak klorofil daun salam dengan energi gap terkecil dapat dikatakan sebagai sensitizer terbaik dikarenakan dengan energi gap akan memudahkan suatu elektron untuk mengalami eksitasi dari pita valensi ke pia konduksi (Aryanti., 2016), (D. Ganta, 2017). Semakin mudah elektron mengalami eksitasi maka semakin banyak pula elektron yang yang mengalir sehingga sifat kelistrikan yang dihasilkan semakin tinggi (Sze, 2001), (Prajitno., 2015). Sesuai dengan penelitian sebelumnya yang telah dilakukan oleh Azizah (2018) bahwa klorofil pada pH asam mengalami electronic coupling antara LUMO dan $\mathrm{TiO}_{2}$, menyebabkan level Fermi $\mathrm{TiO}_{2}$ dan potensial elektrolit berkurang dengan seiring bertambahnya ion $\mathrm{H}^{+}$, sehingga proses transfer elektron meningkat.

\section{Kesimpulan}

Berdasarkan hasil dari pengujian dan anlisis data yang dilakukan, dapat ditarik kesimpulan bahwa spectrum serapan UVVis pada ekstrak klorofil daun salam dengasn berbagai variasi $\mathrm{pH}$ mengandung senyawa klorfil dengan rentang panjang serapan sebesar 468,50-662,50 nm, HOMO DAN LUMO pada ekstrak klorofil daun salam memenuhi persayaratan yang telah ditetapkan, sehingga ekstrak daun salam berpotensi sebagai sensitizer pada DSSC. Dari hasil penelitian ini ekstrak klorofil daun salam terbaik berapada pada pada $\mathrm{pH} 1$, hal ini dikarenakan pada ekstrak klorofil daun salam pH 1 memiliki energi gap terkecil yaitu sebesar $0.606 \mathrm{eV}$, sehingga memiliki potensin yang lebih tinggi sebagai sensitizer pada DSSC. Untuk penelitian lebih lanjut dapat dilakukan pengaplikasian pada DSSC dengan memanfaatkan ekstrak klorofil daun salam $\mathrm{pH} 1$ untuk mendapatkan efisiensi yang tinggi pada kerja DSSC.

\section{Ucapan Terima Kasih}

Ucapan terima kasih kepada pengelolah Laboratorium Jurusan Kimia FMIPA Unesa dan pihak yang telah membantu yaitu dosen pembimbing yang telah membantu jalannya penelitian ini sehingga dapat selesai dengan tepat pada waktunya 


\section{Daftar Pustaka}

Al-Alwani MAM, M. A, 2015. Effect of solvents on the extraction of natural pigments and adsorption onto $\mathrm{TiO} 2$ for dye-sensitized solar cell applications. Spectrochimica Acta Part A: Molecular and Biomolecular Spectroscopy, 130-137.

Al-Alwani, M. A., Mohamad, A. B., Kadhum, A. A., Ludin, N. A., Safie, N. E., Razali, M. Z., Sopian, K., 2017. Natural dye extracted from Pandannus amaryllifolius leaves as sensitizer in fabrication of dye-sensitized solar cells. Int. J. Electrochem. Sci.,, 747761.

Aryanti., N., 2016. Ekstraksi Dan Karakterisasi Klorofil Dari Daun Suji (Pleomele Angustifolia) Sebagai Pewarna Pangan Alami. J. Apl. Teknol. Pangan, 129-135.

Ayele, W. A., 2016. Dye-sensitized solar cells using natural dye as lightharvesting materials extracted from Acanthus sennii chiovenda flower and Euphorbia cotinifolia leaf. $J$. Sci. $A d v$. Mater. Devices, 488-494.

Aziza Hfii Ahliha, F. N., 2018. Kajian pH Klorofil Terhadap Ikatan Kimia Dye pada $\mathrm{TiO} 2$ sebagai Aplikasi DyeSensitized Solar Cell (DSSC). Jurnal Fisika dan Aplikasinya, 16-19.

D. Ganta, J. J., 2017. Dye-sensitized solar cells using Aloe Vera and Cladode of Cactus extracts as natural sensitizers. Chem.Phys. Lett, 97-101.

D. Ganta, J. J., 2017. Dye-sensitized solar cells using Aloe Vera and Cladode of Cactus extracts as natural sensitizers. Chem. Phys. Lett, 97-101.

D. Sinha, D. D., 2020. Photo sensitizing and electrochemical performance analysis of mixed natural dye and nanostructured $\mathrm{ZnO}$ based DSSC. Sadhana - Acad. Proc. Eng. Sci., 175.

Grätzel, B. O., 1991. A low-cost, highefficiency solar cell based on dye sensitized colloidal $\mathrm{TiO} 2$ films. Nature, 353, 737-740.
Grätzel, M., 2003. Dye-sensitized solar cells. Journal of Photochemistry and Photobiology C: Photochemistry Reviews, 4(2), 145-153.

Gusiak, N. K., 2011. Organik Dye Sensitisers For Solar Cells And Semikonduktor Photocatalysts- A Method For Suitability Evaluation Explained. . Biblioteka Cyfrowa Polithechniki Krakowskiej, 60-73.

J. Bisquert, J. G.-C., 2003. Comparative analysis of photovoltaic principles governing dye-sensitized solar cells and p-n junctions. Journal Spin Use 6, 5215.

J. Gong, K. S., 2017. Review on dyesensitized solar cells (DSSCs). Advanced techniques and research trends. Renew Sustain. Energy Rev, 234-246.

K. Sharma, V. S., 2018. Dye-Sensitized Solar Cells: Fundamentals and Current Status. Nanoscale Res. Lett, 381.

K. Tennakone, G. K., 1996. Efficient photosensitization of nanocrystalline $\mathrm{TiO} 2$ films by tannins and related phenolic substances. Journal of Photochemistry \& Photobiology.

K. Wongcharee, V. M., 2007. Sol. Energy Mater. Sol. Cells.

L. G. Oktariza, B. Y., 2018. Performance of dye sensitized solar cells (DSSC) using Syngonium Podophyllum Schott as natural dye and counter electrode. AIP Conf. Proceeding, (p. 1958).

M. A. M. Al-Alwani, A. B., 2019. Performance of the dye-sensitized solar cells fabricated using natural dyes from Ixora coccinea flowers and Cymbopogon schoenanthus leaves as sensitizers. Int. J. Energy Res., 72297239.

M.M. Noor, M. B., 2011. Int. J.Photoenergy, 5.

Milne, F. B., Toker, Y., Rubio, A., \& Nielsen, a. S, 2015. Unraveling the intrinsic Color of Chlorophyll. 
Angewandte Chemie International Edition 54, 2170-2173.

Muhandri., D. R., 2019. Pengaruh Fortifikasi Zat Besi Menggunakan FeSulfat, Fe-Fumarat dan Na Fe EDTA Terhadap Kualitas Sensori ProdukProduk Olahan Tepung Terigu The Effect of Iron Fortification using FeSulfat , Fe-Fumarata and Na Fe EDTA on Sensory Quality of Wheat Products. Jurnal IPB, 54-62.

Prajitno., I. H., 2015. Pengaruh Penggunaan Gel-Electrolyte pada Prototipe. . J. SAINS DAN SENI ITS, 2337-3520.

R. Amelia, D. D., 2014. Fabrikasi Dye Sensitized Solar Cell (DSSC) dengan Sintesis Dye Komposit dari Garcinia mangostana, Celosia cristata, Beta vulgaris rubra dan Musa aromatica pada Fraksi Volume. J. Tek. POMITS, 1-5.

Rendy Rohmatul Maulid, A. N., 2015. Kadar Total Pigmen Klorofil dan Senyawa Antosianin Ekstrak Kastuba (Euphorbia pulcherrima) Berdasarkan Umur Daun. Seminar Nasional Konservasi dan Pemnafaatan Sumber Daya Alam 2015, 225-230.

Rimbi Rodiyana Sova and Pirim Setiarso., 2021. Studi Elektrokimia Klorofil dan Antosianin Sebagai Fotosensitizer DSSC (Dye-Sensitized Solar Cell).
UNESA Journal of Chemistry, 191199.

Rossi., M., 2017. Chlorophylls and xanthophylls of crop plants as dyes for Dye-Sensitized Solar Cells (DSSC). J.Plant Sci. Phytopathol., 087-094.

S. Kim, J. L., 2006. J. Am. Chem. Soc, 128.

S. R. Alfidharisti, F. N., 2017. . Influence of electrode spacing on the efficiency of dye-sensitized solar cell. J. Phys. Conf. Ser., 36-40.

Setiarso., A. S., 2016. Pembuatan Elektroda Pasta Karbon Termodifikasi Zeolit Untuk Analisis Fenol Secara Cyclic Stripping Voltammetry. UNESA J. Chem, 8693.

Sumenda, L., 2011. Analisis Kandungan Klorofil Daun Mangga (Managifera Indica L.) Pada Tingkat Perkembangan Daun Yang Berbeda. Bioslogos, 1 .

Syafinara, R., Gomesh, N., Irwanto, M., Fareq, M., \& Irwan, Y., 2015. Chlorophyll Pigments as Nature Based Dye for Dye-Sensitized Solar Cell (DSSC). Energy Procedia, 896902.

Sze, S., 2001. Semikonduktor devices Physics and Technology 2nd. Taiwan: Printed in the United States of America. 